\title{
Assessing flood risk for a rural detention area
}

\author{
S. Förster ${ }^{1}$, B. Kuhlmann ${ }^{2}$, K.-E. Lindenschmidt ${ }^{3}$, and A. Bronstert ${ }^{1}$ \\ ${ }^{1}$ University of Potsdam, Department of Geo-ecology, Karl-Liebknecht-Str. 24-25, 14476 Golm, Germany \\ ${ }^{2}$ Justus Liebig University of Gießen, Institute for Farm Management, Senckenbergstraße 3, 35390 Gießen, Germany \\ ${ }^{3}$ GeoForschungsZentrum Potsdam, Engineering Hydrology Section, Telegrafenberg, 14473 Potsdam, Germany
}

Received: 13 November 2007 - Revised: 21 February 2008 - Accepted: 26 March 2008 - Published: 10 April 2008

\begin{abstract}
Flood detention areas serve the primary purpose of controlled water storage during large flood events in order to decrease the flood risk downstream along the river. These areas are often used for agricultural production. While various damage estimation methods exist for urban areas, there are only a few, most often simpler approaches for loss estimation in rural areas. The loss assessment can provide an estimate of the financial provisions required for the farmers' compensation (e.g., in the context of cost-benefit analyses of detention measures).

Flood risk is a combination of potential damage and probability of flooding. Losses in agricultural areas exhibit a strong seasonal pattern, and the flooding probability also has a seasonal variation. In the present study, flood risk is assessed for a planned detention area alongside the Elbe River in Germany based on two loss and probability estimation approaches of different time frames, namely a monthly and an annual approach. The results show that the overall potential damage in the proposed detention area amounts to approximately $40000 € \mathrm{a}^{-1}$, with approximately equal losses for each of the main land uses, agriculture and road infrastructure. A sensitivity analysis showed that the probability of flooding (i.e., the frequency of operation of the detention area) has the largest impact on the overall flood risk.
\end{abstract}

\section{Introduction}

Flood risk management measures aim to reduce the negative effects of floods. The designation of detention areas as one of these measures is currently being discussed for the Elbe and many other rivers. Several sites along the middle course of the Elbe River (Germany) have already been proposed as po- tential locations for flood detention, and were investigated in terms of flood peak reduction potential (IKSE, 2003; Helms et al., 2002). However, stakeholders, such as farmers, are reluctant to allow allocation of agricultural lands for flood detention, because of the negative effects inundated waters have on agricultural lands (crop losses, excessive sediment and contaminant deposition, potential degradation of the soil, etc.). In order to provide decision support for this controversial debate, it is necessary to have an in-depth assessment of the flood risk of the proposed sites.

The objective of the present study is to investigate the effect of time-varying damage in the flood risk assessment of rural flood prone areas. The concept is tested at a proposed flood detention area at the Elbe River. Section 1 gives a short overview of flood loss estimation methods with a focus on rural damage. It shows that agricultural losses have a strong seasonal variation, while the flooding probability also varies with seasons. In order to account for this variability, flood risk that is to be expected for the detention area is assessed based on two loss and probability estimation approaches of different time frames, namely a monthly and an annual approach (Sect. 2). During the large Elbe flood in August 2002, an area of $200 \mathrm{~km}^{2}$ on the right side of the Elbe River including the proposed detention site was flooded due to several dike failures (BfG, 2002). This flood event enables a validation of the damage estimation methods using damages recorded at the municipal level (Sect. 3). In a sensitivity analysis the relative importance of the factors crop share, market price and probability of polder operation were investigated (Sect. 4). Finally, the two different flood loss estimation methods, their applicability in other locations, and the potential impact of future developments (i.e., land-use changes, frequency of polder operation) on the results are discussed.

Correspondence to: S. Förster

(forster@uni-potsdam.de) 
Table 1. Comparison of case studies on flood damage estimation including agriculture losses regarding the considered flood variables.

\begin{tabular}{|c|c|c|c|c|}
\hline Reference (case study site) & Submersion period & Water depth & Submersion duration & Flow velocity \\
\hline Hoes and Schuurmans, 2005 (The Netherlands) & no & stage-damage curve & no & no \\
\hline Neubert and Thiel, 2004 (Gemany) & yes (four periods per year) & no & no & no \\
\hline Dutta et al., 2003 (Japan) & yes (monthly) & yes (three classes) & duration-damage curve & no \\
\hline Citeau, 2003 (France) & yes (monthly) & yes (three classes) & yes (four classes) & yes (three classes) \\
\hline Consuegra et al., 1995 (Switzerland) & yes (15-day period) & no & yes (two classes) & no \\
\hline
\end{tabular}

\subsection{Damage estimation methods}

This study estimates losses associated with the flooding of a detention area in a rural environment. The review of flood loss estimation methods, therefore, focuses on floodwater damage to croplands and grasslands and road infrastructure, which are typical land-use types in such flood detention areas.

Flood damage estimation methodologies are applied in many countries in Europe (Meyer and Messner, 2005) and worldwide (Dutta et al., 2003). Theses methods are useful in conducting cost-benefit analyses of the economic feasibility of flood control measures. In Germany, responsibility for flood policy lies with the individual federal states and, hence, there are large differences in the character and application of flood estimation methods in these states. The investigated site is located in the federal state of Saxony-Anhalt, where damage evaluation is still rarely used, according to Meyer and Messner (2005). However, with the implementation of the new European Directive on flood risk management (EC, 2007) and the increasing availability of data, it is expected that damage evaluation will gain more importance in flood defence planning in the coming years.

Expected losses in rural areas are typically much lower than those in urban areas. Hence, damage evaluation in rural areas is often neglected or only accounted for by using simple approaches and rough estimates.

Pivot et al. (2002) differentiate between losses due to damage to crops grown at the time of flooding, and damage affecting soil characteristics. The first is mainly due to the anoxia suffered by the crop, the water column pressure and locally the flow of the water. It results in a reduction in yield and crop quality and may require additional expenditures for sowing, tillage, and the application of fertiliser and crop protective agents. The second refers to a potential decrease in the quality of soil due to pollutant deposition and a loss of soil structure due to compaction or erosion.

Main variables that define the flood damage to agricultural lands are the time of year of flood occurrence, water depth, duration of flooding, flow velocity, and deposition of pollutants (DVWK, 1985; LfL, 2005; Citeau, 2003). Many authors point out that the time of occurrence of a flood with respect to crop growth stages and critical field operations plays a crucial role in the magnitude of damage (Penning-
Rowsell et al., 2003; Todorovic and Woolhiser, 1972). This differs significantly from damage evaluation in other damage categories, for example damage to buildings where loss potential does not vary with the seasons. For example, flooding in June/July results in much higher losses for summer grain crops just prior to harvesting than flooding in August just after harvesting. Depending on the time of flooding and the affected crop types, the farmers may decide to undertake measures in order to alleviate overall loss. USDA (1978) lists measures to alleviate flood losses depending on the time of year categorised in half-month periods for pasture and several crop types. For example, it may be possible to replant winter wheat in October with no or low yield reduction, whereas it may be too late for replanting in November, the only option being to plant a substitute spring crop. This saves costs for the harvesting of winter wheat but necessitates additional tillage operations. Generally, loss estimates should be developed for each crop type and period of flooding, making allowance for yield losses due to delayed planting, replanting costs, savings due to costs not incurred, and costs for clean-up.

Table 1 summarises the agricultural damage variables that have been accounted for in selected case studies of flood damage estimation. In most case studies, time of occurrence is considered whereas the flood variables water depth, inundation duration, and flow velocities are only included in a few case studies. This is because the data needed to quantify the impact of these variables on the expected damage are sparse. Citeau (2003) gives a rough estimate of maximum tolerable submersion time, inundation depth, and flow velocity for different rural land-use types. The maximum tolerable levels refer to the conditions that plants are expected to withstand without severe damage. The estimates were derived from a survey among farmers in France. According to Citeau (2003), maximum tolerable inundation duration for cropland varies between three days in spring/summer to one month in autumn/winter. Maximum tolerable depth of submersion strongly depends on the type of land use and vegetation height. Examples provided in Citeau (2003) are $1 \mathrm{~m}$ for orchards and $0.5 \mathrm{~m}$ for vineyards. Maximum flow velocities vary between $0.25 \mathrm{~m} \mathrm{~s}^{-1}$ for field vegetables and $0.5 \mathrm{~m} \mathrm{~s}^{-1}$ for orchards. No velocity values are provided for cropland. High flow velocities can cause direct damage to the plants and to soil degradation from erosion (LfL, 2005). 


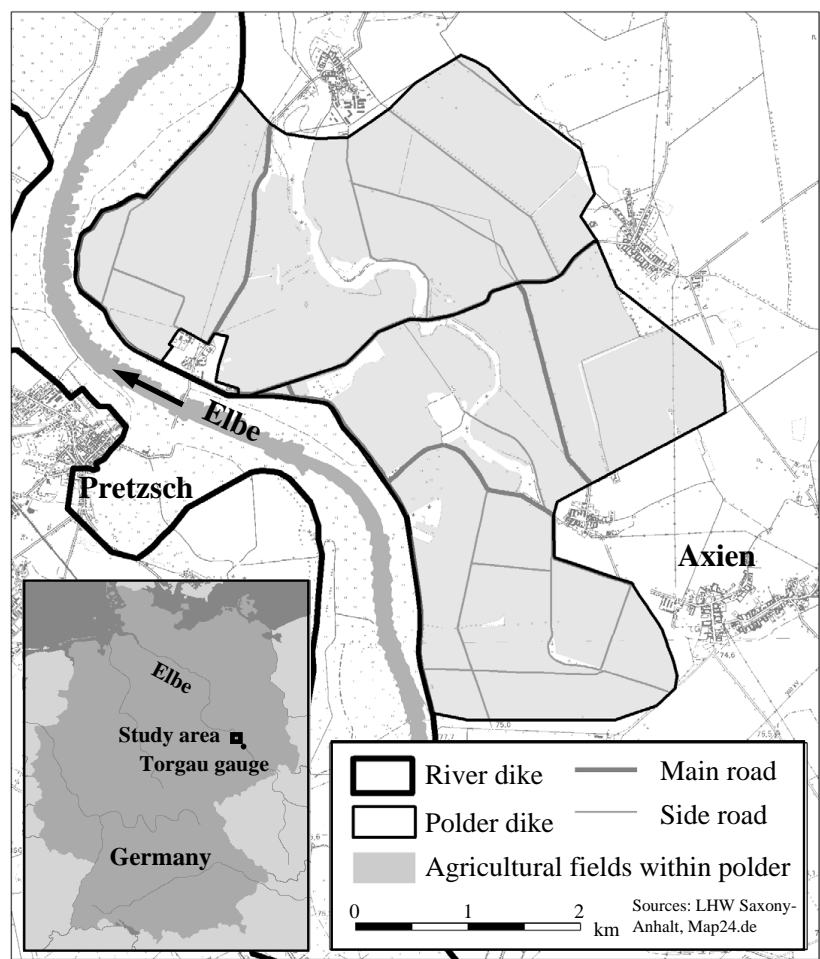

Fig. 1. Detention area with agricultural fields and road system. It is confined by the Elbe main dike to the river and polder dikes to the hinterland.

Another variable causing agricultural losses is the deposition of waste and mud that might contain pollutants. Such losses often necessitate additional clean-up costs, and the inundated crops and vegetables may not be sold due to contamination.

Other agricultural goods that may be susceptible to flood damages are farm buildings, machinery, and infrastructure (e.g. roads). In contrast to crop and grassland losses, damage in these other categories is independent of the season. Usually stage-damage functions are applied which relate the water level to the relative expected damage. In order to obtain an estimate of the total expected loss, the relative damage is related to the maximum damage per area and land-use type (Merz et al., 2004). Indirect losses due to traffic and business interruptions are usually estimated as a proportion of direct costs (YRFCMP, 2003).

\subsection{Study site}

The present-day embankments confining most of the German reaches of the Elbe River date back to the 2nd half of the 19th century, although dike construction along the Elbe began as early as the 12 th century. The embankments have led to a reduction of the retention area in Germany from $6172 \mathrm{~km}^{2}$ to $838 \mathrm{~km}^{2}$ (13.6\% of original). The reduction of retention areas and the straightening of the main river channel have

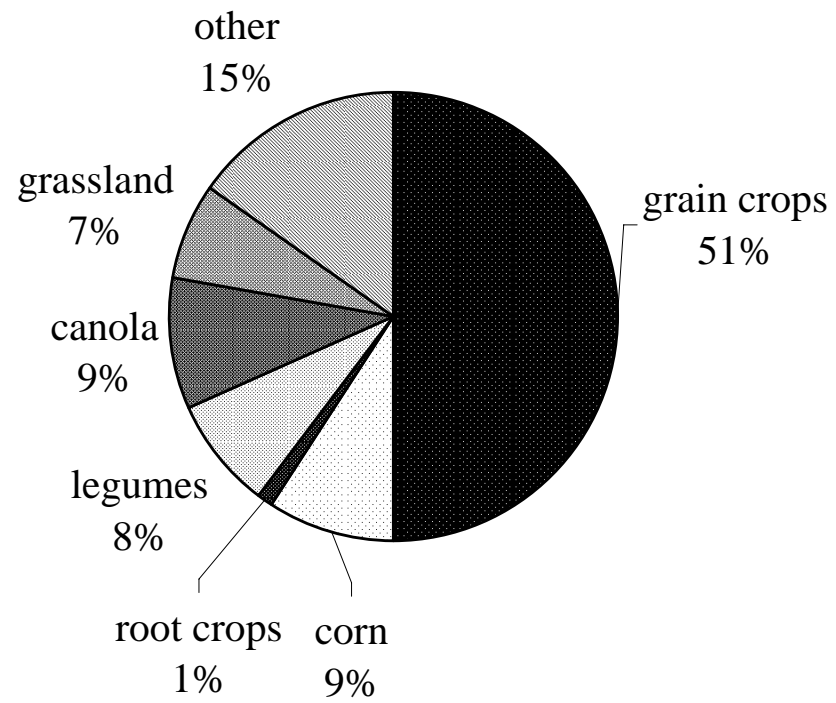

Fig. 2. Land use of the study site (\% of agricultural land).

resulted in an acceleration of flow velocity and an increase of the flood water levels (BfG, 2002).

Today the construction of detention sites in the former inundation area along the Elbe is being discussed. Such sites would enable controlled diversion and storage of excess water during large flood events in order to reduce flood risk adjacent to and downstream from the detention areas.

In the present study, one large controlled detention area was investigated that is already in the early planning stages (Fig. 1). It is situated alongside the right bank of the middle course of the Elbe River between the Torgau and Wittenberg gauges and is designed for reducing flood peaks having a 100-years or more recurrence interval. The storage capacity is 40 million $\mathrm{m}^{3}$. The detention area consists of agricultural land with very fertile soils and high agricultural productivity. More than $90 \%$ of the land is currently under intensive agricultural use. The remaining $10 \%$ of the area consists of watercourses and forest. There are no settlements within the proposed detention area. It is expected that the area will retain its present function as agricultural land even after it has been designated as a detention area.

In order to estimate the expected flood losses on agricultural lands in the detention area, information is needed on the type and mixture of crops typically grown on those lands. The agricultural land-use types for the years 2002 to 2007 were collected by interviewing the local farmers. The farmers' decision about which crops to grow depends on the profit margins for different crops and the farmers' goal, which is assumed to be profit maximization. Grain crops are grown on $51 \%$ of the agricultural area due to the good soil quality in the former inundation area (Fig. 2). Main grain crops grown in the study area are wheat and barley. Corn (9\%) is used for energy production and silage fodder. The share of grassland is comparatively low (7\%). Grass is usually cut three times 
Table 2. Market value of selected crops for the administrative region of Dessau/Saxony-Anhalt averaged over the years 2000 to 2005 .

\begin{tabular}{lllllllll}
\hline crop & wheat & rye & barley & corn & canola & potatoes & sugar beets & grassland \\
\hline market value $(€ /$ ha) & 704 & 459 & 605 & 883 & 632 & 2339 & 2103 & 266 \\
\hline
\end{tabular}

Table 3. Damage impact factors for wheat and grass for different months of the year grouped by different durations of flooding. Values have been extended from LfUG (2005).

\begin{tabular}{llllll}
\hline & \multicolumn{2}{c}{ Wheat } & Grassland \\
\hline inundation duration & $1-3$ days $(\%)$ & $4-7$ days $(\%)$ & $8-11$ days $(\%)$ & $>11$ days $(\%)$ & $1-11$ days $(\%)$ \\
January & 5 & 10 & 20 & 80 & 5 \\
February & 5 & 10 & 20 & 80 & 5 \\
March & 5 & 10 & 20 & 80 & 10 \\
April & 10 & 25 & 40 & 80 & 20 \\
May & 20 & 40 & 70 & 100 & 50 \\
June & 50 & 50 & 80 & 100 & 15 \\
July & 100 & 100 & 100 & 100 & 20 \\
August & 100 & 100 & 100 & 100 & 30 \\
September & 0 & 0 & 0 & 0 & 10 \\
October & 5 & 10 & 20 & 80 & 10 \\
November & 5 & 10 & 20 & 80 & 10 \\
December & 5 & 10 & 20 & 80 & 10 \\
\hline
\end{tabular}

per year and is mainly used for fodder production.

\section{Methodology}

Risk is defined as the probability of the adverse effects of a natural process, such as a flood, exceeding a certain magnitude (intensity) from which certain damages and losses occur (vulnerability) (Merz et al., 2007). For the detention area, the probability of flooding corresponds to the probability of opening the inlet gate for flood water diversion, which would be the case for large floods with return periods exceeding 100 years. The costs are associated with the flood losses on agricultural land and the road system within the detention area. Since loss on agricultural land has a seasonal variation, the flood frequency analysis provides monthly weights on the flooding probability. The annual monetary flood loss in $€$ per hectare per year $\left(€ \mathrm{ha}^{-1} \mathrm{a}^{-1}\right)$ on agricultural fields is calculated by weighting the loss from a single flood event occurring in each month with the probability of flooding in that month (Hess and Morris, 1987).

\subsection{Damage estimation}

Several approaches of varying complexity are available to calculate losses in agricultural production due to flooding. This study applies two approaches, using a monthly and an annual time frame for loss estimation.
A damage estimation model based on a monthly disaggregation of damages to crops and grasslands was developed within the framework of the project "Methods for the evaluation of direct and indirect flood losses" (MEDIS, 2007). The expected damage for each crop is calculated by:

$E D=M V \cdot \sum_{m=1}^{12} P M_{m} \cdot D I_{m}$

where $E D=$ expected damages (monetary losses in $€$ ha $^{-1}$ $\mathrm{a}^{-1}$ ), $M V=$ market value (that can be obtained by the harvested crop without flooding in $\left.€ \mathrm{ha}^{-1}\right), P M=$ probability of polder flooding every 100 years for a certain month $m\left(\mathrm{a}^{-1}\right)$ and $D I=$ damage impact on crops for month $m(\%)$. The market value $M V$ is calculated by the total yield of a crop harvested multiplied by its selling price. $M V$ differs from region to region since the crop yield is dependent on the climatic and soil conditions and the type of agricultural management practices used. Germany can be subdivided politically into 38 administrative regions, each of which has different $M V$ values for each crop. The $M V$ values for each region were derived from the standard gross margins provided by the Curatorship for Technology and Construction Engineering in Agriculture (KTBL, 2007). The $M V$ values for the administrative region of Dessau/Saxony-Anhalt, in which the study site lies, are given in Table 2 for selected crops.

The damage impact factor $D I$ depends on the type of crop, the month of the flooding occurrence, and the inundation 


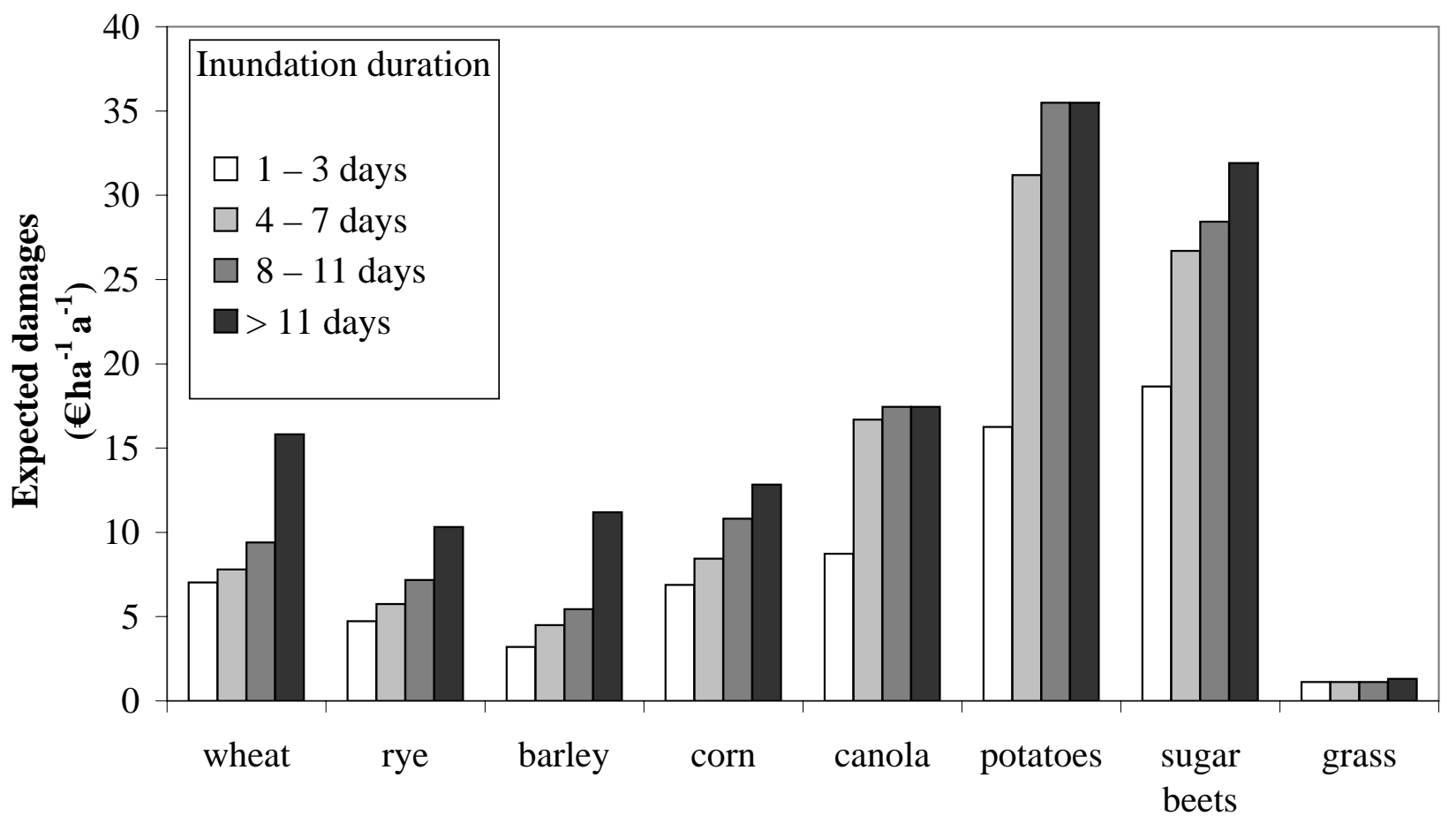

crop

Fig. 3. Expected damages to grain crops (wheat, rye, barley, corn), oilseed plants (canola), root crops (potatoes and sugar beets) and grass based on flooding occurrence categorized on a monthly basis. Data are derived from LfUG (2005), KTBL (2006) and KTBL (2007). It is assumed that the inundation duration of $>11$ days classification corresponds to the degree of damage expected to occur within the polders.

duration. Table 3 gives an example of damage impact percentages for wheat and grass for each month. The information is based on empirical data from surveys in France and Germany as referenced in LfUG (2005) and expert knowledge. The damage impact factors can reach values of up to $100 \%$ indicating a total loss. The impact is particularly dependent on the growth stage of each crop. Root crops and grain crops are harvested once per year and their impact factors have patterns similar to the ones shown for wheat. Their impact factors are differentiated into four classes of inundation duration. Grass is an exception to the other crops because it can usually be harvested three times per year (May, July, and August). The total annual yield of grass is distributed throughout the year in three harvests in May, July, and August with an annual average of 50\%, 20\% and 30\%, respectively. Hence, the impact factors are lower since only a fraction of the total yearly harvest is damaged by a flood. The impact factors are also independent of inundation duration because sediment deposition on grasslands occurs after every flood, regardless how short the inundation period is, making the grass unusable for high value fodder. For inundation times longer than about 10 days, additional costs may be incurred due to structural damage to the grass roots requiring a repair seeding of the grasslands. The costs for the repair seeding of grasslands, which includes seeds, labour and machinery are approximately $45 € \mathrm{ha}^{-1}$ (KTBL, 2006).

Figure 3 shows the expected damage for each crop differentiated into classes of inundation duration. The maximum damage is expected to vary between 10 and $16 €$ $\mathrm{ha}^{-1} \mathrm{a}^{-1}$ for grain crops and between 32 and $36 € \mathrm{ha}^{-1} \mathrm{a}^{-1}$ for root crops based on an inundation duration of more than 11 days. Damages for grass are the lowest at approximately $1 € \mathrm{ha}^{-1} \mathrm{a}^{-1}$.

In addition to the monthly damage estimation model, an annual approach was applied in which only two land-use classes were distinguished and the time within the growing season when the flooding occurs was not considered. Damages with the annual approach are calculated by:

$E D=M V \cdot R D \cdot P A$

where $E D=$ expected damages (monetary losses in $€ \mathrm{ha}^{-1} \mathrm{a}^{-1}$ ), market value (that can be obtained from the agricultural land without flooding in $€ \mathrm{ha}^{-1}$ ), $R D=$ relative damage costs $(\%)$ and $P A=$ probability of polder flooding every 100 years (i.e. $0.01 \mathrm{a}^{-1}$ ).

The agricultural land was differentiated in arable land and grassland with market values of 4000 and $2000 € \mathrm{ha}^{-1}$, respectively. These figures are based on damage claims from past extreme flood events in the state of Saxony in Germany (LfUG, 2005).The relative damages to both, regardless 
of flood depth, inundation duration or the time within the growing season, were set to be $50 \%$ and $10 \%$, respectively. According to LfUG (2005), these values were found to fit recorded damages in flat inundation areas best. In comparison, relative damages in mountainous areas with discharges of $1 \mathrm{~m}^{2} \mathrm{~s}^{-1}$ increase to $75 \%$ and $25 \%$, respectively. The damage to be expected when operating the polders to cap floods that exceed discharges with return periods of more than 100 years are $20 € \mathrm{ha}^{-1} \mathrm{a}^{-1}$ for arable farmland and $2 € \mathrm{ha}^{-1} \mathrm{a}^{-1}$ for grassland. These damage values are of the same order of magnitude as the damages calculated on a monthly basis (compare Fig. 3).

In order to provide a representative picture of the current land-use situation, including crop rotation schemes, the percentage shares of crop types and grassland were averaged over the last 5 years (2003-2007). For the annual approach, this information was aggregated into two classes of arable land and grassland.

During the large flood in August 2002 having a return period of approximately 180 years near the study site the region where the proposed detention basin would be located was flooded as a result of dike failures. Afterwards losses were recorded by the authorities for compensation purpose. Economic loss information for agricultural land on the municipal level was made available for the present study. In order to assess the quality of the results, recorded loss data for one municipality were compared with estimated losses for the same municipality. The municipality was chosen because it has a share of the proposed detention area and was almost completely inundated in 2002, as indicated by satellite imagery. Settlements were less affected because they are built on slightly higher elevated ground. Analogous to the detention area, data on the percentage of crop types and grassland in the selected municipality were collected.

Besides losses in the agricultural sector, infrastructure damage in the form of damage to the road system is considered to be the other major damage component in the study area. Information on length and width of the roads was collected from aerial photographs and field surveys. The expected damage to the road system was then calculated by:

$E D=R C \cdot R D \cdot P A$

where $E D=$ expected damages (monetary losses in $€$ $\left.\mathrm{ha}^{-1} \mathrm{a}^{-1}\right), R C=$ replacement costs $\left(€ \mathrm{ha}^{-1}\right), R D=$ relative damage (\%) and $P A=$ probability of polder flooding every 100 years (i.e. $0.01 \mathrm{a}^{-1}$ ). Based on damages recorded during past flood events, damage to the traffic system is given as $200 € \mathrm{~m}^{-2}$, whereas a relative damage impact factor of $10 \%$ is provided for water depths larger than $1 \mathrm{~m}$ and flow velocities below $1 \mathrm{~m} \mathrm{~s}^{-1}$ (LfUG, 2005). This corresponds closely to repair costs of $25 € \mathrm{~m}^{-2}$ for asphalt roads that were found on the basis of bid prices after the deliberate flooding of a polder system further downstream along the Elbe River (Ellmann and Schulze, 2004). For a probability of flooding of $1 \%$, which corresponds to the operation of the pold- ers every 100 years, the expected damages would amount to $2000 € \mathrm{ha}^{-1} \mathrm{a}^{-1}$. Although this value is high compared to the expected damages for arable land and grassland obtained with the annual approach, the total road surface area is substantially less than that taken up by agricultural fields.

In the present study loss estimation is restricted to direct tangible damage. Indirect damage such as traffic interruption is considered to be relatively small in the rural study area. Since the detention area is not inhabited and the people will be warned prior to the polder operation, no victims or loss of livestock is expected. Intangible damage is mainly expected in the form of adverse impacts on flora, fauna, and the terrestrial and aquatic ecosystem in the affected area. In particular, the water quality degradation from flooding can have negative effects on the fish fauna as reported in studies on storage basins and floodplains (Knösche, 2003; Howitt et al., 2007). This aspect will be part of future work on the same detention area.

\subsection{Flood frequency analysis}

As the costs associated with flooding of agricultural land are differentiated on a monthly basis, the expected percentage distribution of damaging floods was also analysed monthly using the discharge recorded from the gauge at Torgau for the time period 1936-2004. The Torgau gauge is located approximately $30 \mathrm{~km}$ upstream of the proposed detention area. There are no relevant tributaries on the river stretch between the gauge and the detention site. Figure 4 shows the monthly distribution of all flood peaks in the annual maximum series (AMS) and of the largest $10 \%$ of the AMS flood events. $73 \%$ of the flood events in the AMS occur during the hydrological winter season from November to April (with more than $30 \%$ of the events occurring in March). July and August events constitute $12 \%$ of the AMS events, however account for $27 \%$ of the largest $10 \%$ of the AMS events. Apparently, there are many AMS events with comparatively small peak discharge values in spring, whereas in summer AMS events are less frequent, but typically larger. This indicates that there is a relation between seasonality of floods and their magnitude, which should be accounted for when determining the monthly percentage distribution of damaging floods. The differentiation into months having different flooding pattern is motivated by the strong dependence of losses on the month of flood occurrence. In Fig. 4, the damage impact factors for wheat are included to illustrate this aspect. Extreme flood events with peak discharges relevant for polder operation have a high probability of occurrence during the summer months shortly before harvest, when grain crops are most vulnerable to inundation.

The seasonality of flood magnitudes is a result of different flood generating mechanisms that are often dominant during different seasons (Lecce, 2000). If this is the case it is advisable to separate the flood series into seasons of similar generation mechanisms. Petrow et al. (2007) investigated 


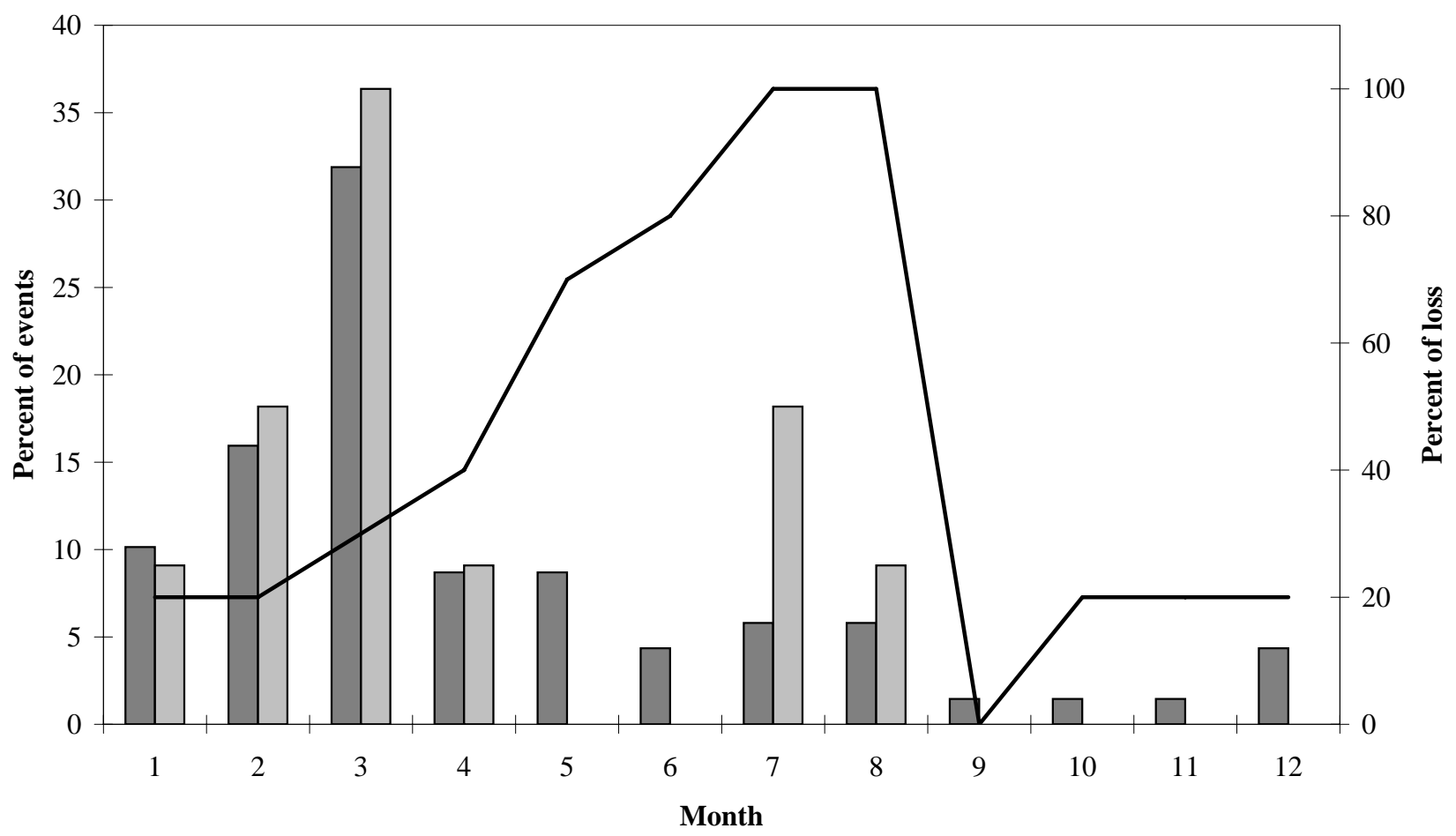

AMS $\square$ largest $10 \%$ of AMS — damage impact factor for wheat

Fig. 4. Seasonality of annual peak flows for all and the 10\% largest events based on the discharge AMS for 1936-2004 at the Torgau gauge and seasonality of the damage impact factor for wheat for inundation durations of 8 to 11 days.

the relation between dominate European atmospheric circulation patterns and annual maximum flood events for a sub-catchment of the Elbe basin. They found that westerly and north-westerly cyclones are responsible for most winter floods, but only play an important role for return periods up to 10 years. Larger floods with return periods larger than 50 years are exclusively generated by a $\mathrm{Vb}$-weather regime, which is characterised by a cyclone system travelling northeastward from the Mediterranean to Central Europe. Sivapalan et al. (2005) propose a method to isolate the contributions of individual months or seasons to the annual flood frequency curve to account for the intra-annual variability in flood processes.

Since the dikes are designed to retain floods with return periods of up to 100 years and hence the detention area is operated only during very large flood events, it is necessary to determine the probability that this discharge will be exceeded. From the Torgau gauge discharge record for the years 19362004, the largest flood in the entire year and in each of the 12 months is picked to construct annual and monthly flood frequency curves (Fig. 5). A composite of the GEV (Generalised Extreme Value) (Kotz and Nadarajah, 2000) and GL (Generalised Logistics) (Johnson et al., 1994) distributions using L-moments gave the best fit to the data. Both distribution functions are widely used in flood frequency analysis.

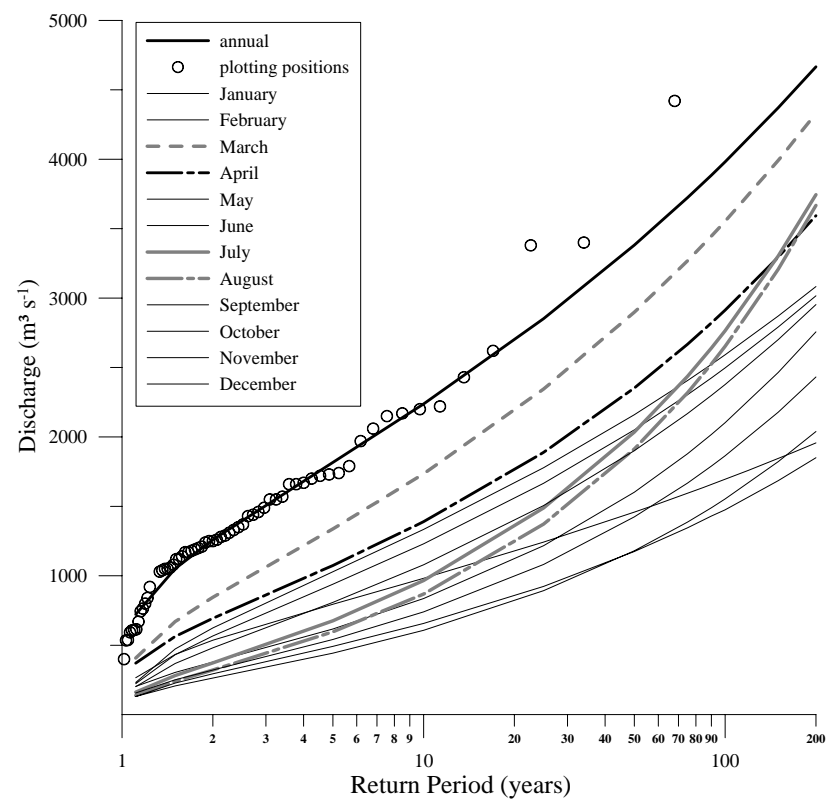

Fig. 5. Flood frequency analyses based on the annual and monthly maximum discharges of the years 1936-2004 at the gauge at Torgau. A composite of the GEV and GL distributions is used. 


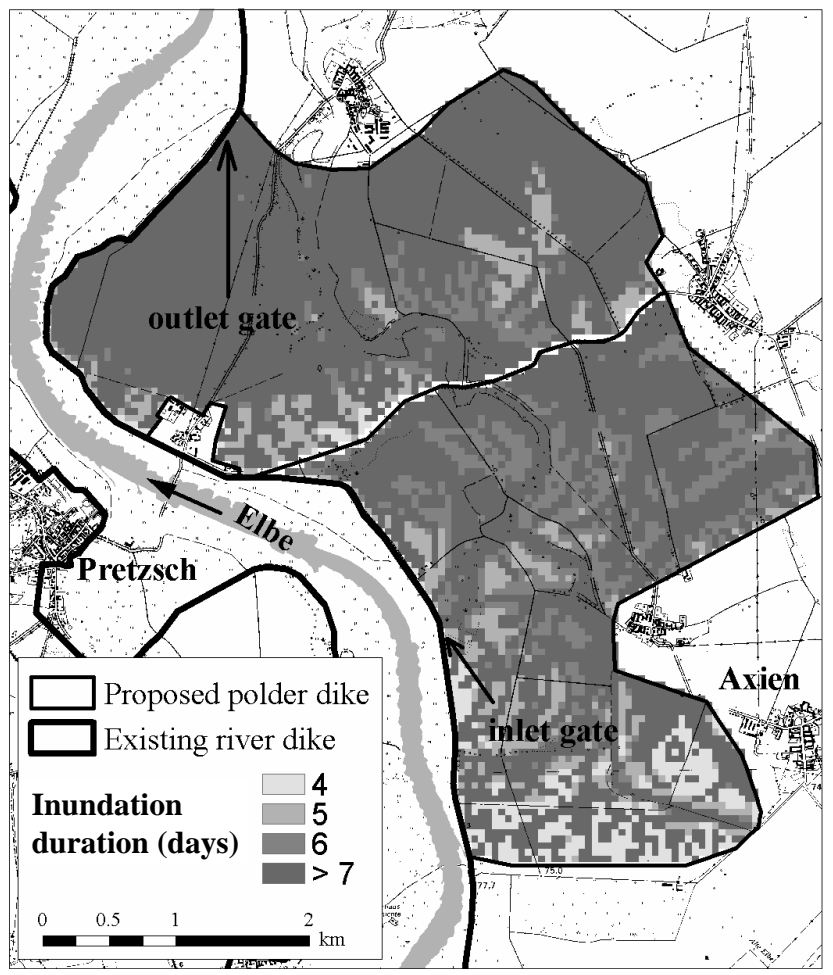

Fig. 6. Simulation results for the flood event of August 2002 (inundation duration in days).

The composite distribution function is a combination of the two functions, which were given equal weights (Merz and Thieken, 2005). Figure 5 shows that the discharge associated with the annual return period of 100 years is $4000 \mathrm{~m}^{3} \mathrm{~s}^{-1}$, while the monthly return periods corresponding to the discharge of $4000 \mathrm{~m}^{3} \mathrm{~s}^{-1}$ are larger (for example about 150 years for March), i.e. the occurrence probabilities smaller. This means that the probability of a flood peak of a certain discharge (for example $4000 \mathrm{~m}^{3} \mathrm{~s}^{-1}$ ) occurring in a particular month is smaller than its probability of occurrence at any time of the year.

\section{Results}

The temporal and spatial distribution of flooding variables, such as inundation duration, water depth, and flow velocity were obtained in previous 2D-hydrodynamic simulations of the same detention site based on the large flood event of August 2002 (Förster et al., accepted ${ }^{1}$; Chatterjee et al., accepted $^{2}$; Huang et al., 2007). Simulated water depths in the

\footnotetext{
${ }^{1}$ Förster, S., Chatterjee, C., and Bronstert, A.: Hydrodynamic Simulation of the Operational Management of a Proposed Flood Emergency Storage Area at the Middle Elbe River, J. River Res. Appl., accepted, 2008.

${ }^{2}$ Chatterjee, C., Förster, S., Bronstert, A.: Comparison of Hydrodynamic Models of Different Complexities to Model Floods
}

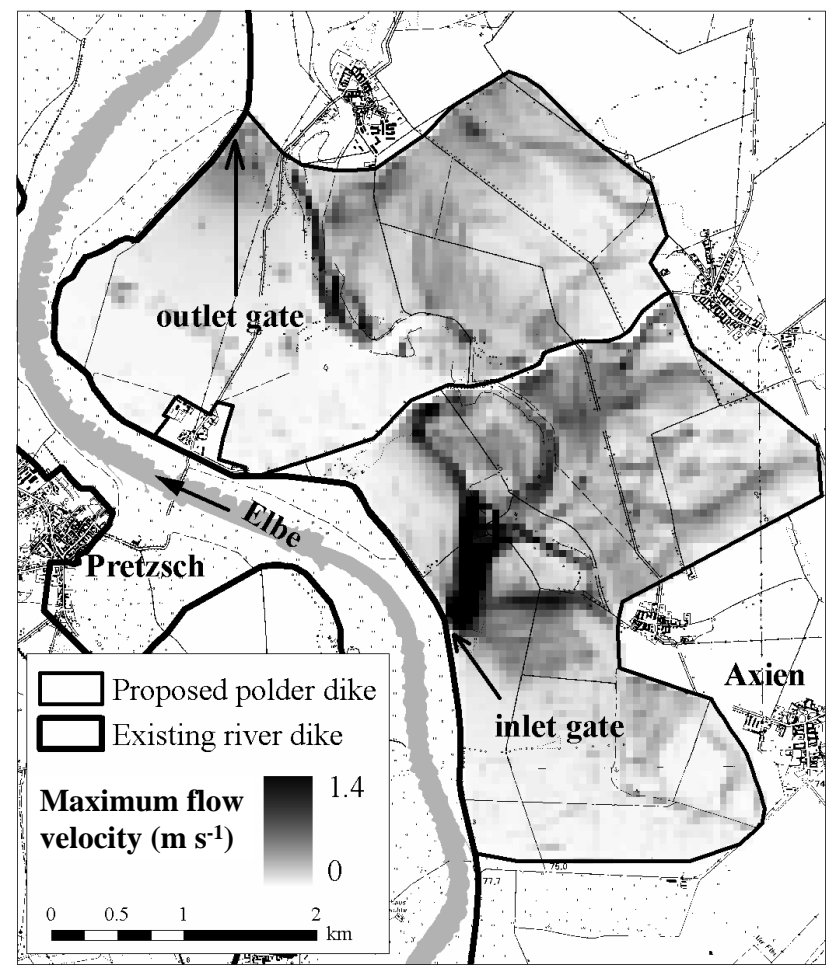

Fig. 7. Simulation results for the flood event of August 2002 (maximum flow velocity in $\mathrm{m} \mathrm{s}^{-1}$ ).

detention area range from $0.5 \mathrm{~m}$ in the higher elevated southern part to $5.7 \mathrm{~m}$ in the central part, with a mean water depth of $2.5 \mathrm{~m}$. The entire detention area remains inundated for three days until the start of the emptying process. After day four, the surface water retreats from only $5 \%$ of the area, whereas $75 \%$ of the area remains inundated for more than one week. Maximum flow velocities of $1.4 \mathrm{~m} \mathrm{~s}^{-1}$ are simulated behind the inlet gate. Areas with maximum flow velocities of more than $1 \mathrm{~m} \mathrm{~s}^{-1}$ are restricted to the stilling basin behind the inlet gate and along an already existing stream through the detention area. Figures 6 and 7 show the spatial distribution of the inundation duration and the maximum flow velocity in the detention area, respectively. The results are based on the 2002 flood event, which was characterised by a rather steep flood hydrograph. Inundation duration is expected to increase for flood events having wider flood hydrographs than the 2002 event, because the emptying process will start not earlier than the Elbe water level falls below a level that allows for safe discharge at the downstream river reaches.

The farmers interviewed stated that most fields were not accessible for machines for several weeks or even months after the August 2002 flood due to high soil moisture and sludge deposition, although the surface flood water had long

with Emergency Storage Areas, Hydrological Processes, accepted, 2008 . 
retreated. Hence, the case of more than 11 days may realistically represent the agricultural damage and was applied in the estimation of the annual damage using the monthly approach.

The estimated annual damage in agricultural fields for the monthly and annual approach amounts to $21400 € \mathrm{a}^{-1}$ and $14600 € \mathrm{a}^{-1}$, respectively. The annual damage to the road system was estimated to be $15800 € \mathrm{a}^{-1}$. Apart from damages to field crops, additional losses to agricultural production due to damages to buildings, machinery, inventory, and clean-up measures occur. They are very site-specific and not easy to estimate. The loss information collected by the authorities for the affected municipalities during the flood in 2002 gives an indication of the magnitude of these additional losses. An average of $11 \%$ for building damages, $3 \%$ for machinery losses, $7 \%$ for inventory losses, and $12 \%$ for clean-up costs out of the overall agricultural losses in the flood affected area was recorded. Together, they make up approximately $30 \%$ of the overall agricultural losses. Adding these additional costs to the loss estimates obtained with the monthly and annual approaches results in overall losses of approximately $30500 € \mathrm{a}^{-1}$ and $21000 € \mathrm{a}^{-1}$, respectively. Together with the estimated loss to the road infrastructure, overall annual damage obtained with the monthly and annual approaches ranges between $46000 € \mathrm{a}^{-1}$ and $37000 € \mathrm{a}^{-1}$, respectively. The negative effects on the total production process of the farming operation (e.g., reduction in animal production from diminished fodder quality, changes in crop rotation, non-fulfillment of delivery contracts) were not considered due to the difficulty in quantifying these effects on a regional scale.

In order to assess the quality of the damage estimation methods, recorded and estimated losses for one representative municipality were compared. The agricultural losses recorded for this municipality for the specific flood event of August 2002 amounted to $644000 €$. Losses in €were estimated with the monthly and annual approaches for the same flood event. As these are event values, annual or monthly flooding probabilities were not considered. Estimated losses using the annual approach are much higher (3569000€) than those using the monthly approach (546000 €). This is because in the annual approach, the damage values are independent of when the flood occurs during the growing season (April-October) and therefore constitute an average of the expected losses. In the monthly approach damage impact factors were applied according to the specific month in which the flood occurred. At the time of flooding at the end of August, most of the cereal fields had already been harvested and, hence, estimated losses were comparatively low. It illustrates the impact that the time of flood occurrence has on the overall loss. Depending on the time of occurrence, the expected agricultural losses associated with a specific flood event in the detention area vary between $287000 €$ in January and $994000 €$ in July.

\section{Sensitivity analysis}

A sensitivity analysis was performed to determine the relative importance of different factors that are directly influenced by humans. The factors included:

1. crop share of agricultural land use

2. market price for crop types $( \pm 20 \%)$

3. probability of polder operation $\left(\mathrm{HQ}_{80}\right)$

To account for the sensitivity of the results to different crop shares, four land-use scenarios were considered, which involved allocating the entire land coverage of the polder area to either grain crops, root crops, energy plants, or grasslands:

- grain crops $-100 \%$ grain crops (wheat, rye, barley)

- root crops - $100 \%$ root crops (potatoes, sugar beets)

- energy $-100 \%$ of crops used for biomass energy production or as biofuels (corn, canola)

- environment - all of the land is converted to grasslands (grass has a lower oxygen demand on overlying flood waters than do tilled fields and, hence, adverse ecological effects, such as stress on fish populations due to oxygen deficiency, will be reduced).

The actual crop production will be a mixture of the scenarios. Figure 8 shows the results of the four scenarios compared to the current land use in the detention area derived using the monthly damage estimation approach. It is evident that grains, canola and corn (grain crops and energy scenarios) do not change the expected damages significantly from the current situation because a majority of the land coverage is currently a mix of these crops. However, focusing on the production of root plants (root crops scenario) would increase damages by $2^{1} / 2$ times. In comparison, expected damages to grasslands (environment scenario) are minute.

Changing the market price of the crops in the current situation by $\pm 20 \%$ would vary the expected damages by the polder operation by approximately the same degree (17\% increase and $22 \%$ decrease in expected damages if the crop price is increased or decreased by $20 \%$, respectively). The probability proved to be a sensitive factor with expected damages doubling if the polders were to cap discharge peaks of flood events having a return period of 80 years (i.e., $Q_{\text {peak }}=3300 \mathrm{~m}^{3} \mathrm{~s}^{-1}$ as opposed to 100 years with $Q_{\text {peak }}=4000 \mathrm{~m}^{3} \mathrm{~s}^{-1}$ ).

\section{Discussion and conclusions}

Although agricultural damage is often low compared with urban or infrastructure damage, it should be accounted for 


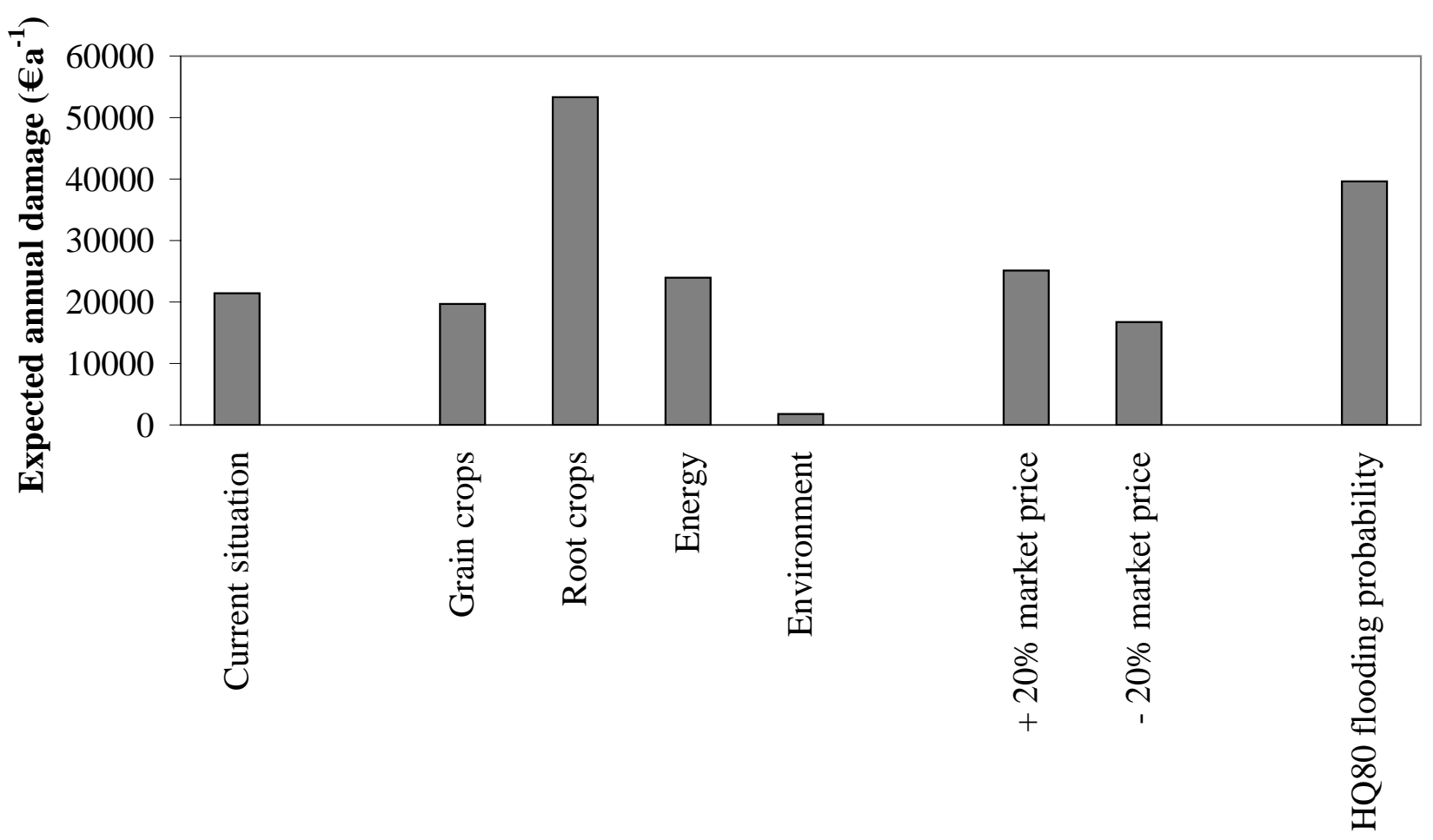

Sensitivity analysis scenario

Fig. 8. Sensitivity of land use, market price and probability of polder operation on the expected damage.

in areas where agricultural production is a predominant activity (Messner et al., 2007). The proposed monthly damage assessment procedure is applicable to a wide variety of agricultural schemes that are characterised by seasonal variation in plant growth and hence expected losses due to flooding.

The damage to agricultural production that results from flooding during a specific flood event mainly depends on the time of occurrence relative to the growth stages and the share of crop types and grassland in the area flooded. Unfortunately, bibliographic sources only provide little information on the resistance of crops to floods (Citeau, 2003). The market value as a product of total yield and selling price varies greatly between the different agricultural landuse types, while each type exhibits a different seasonal pattern of expected losses.

Other damage variables, such as water depth, inundation duration, and flow velocity, are less relevant in case of flooding of an agriculturally-used detention area. This is due to the fact that the water depths are comparatively high in order to provide a large storage volume compared to the ground surface area. In most cases, a total yield loss has to be assumed because of the combined adverse effect of damages and the restricted accessibility after the flooding due to high soil wetness. The operation of detention areas is a special case of inundation in the sense that the flooding occurs deliberately with warning times long enough to undertake mea- sures that alleviate the losses, such as bringing in the harvest, evacuating livestock, or removing machinery from the flood prone area.

The applied monthly and annual approaches are based on market values of the grown crops in order to estimate agricultural production losses, whereas damages to farm buildings, machinery and inventory as well as clean-up costs were not considered. Hence, both damage results are comparable. The comparatively lower estimated annual damages obtained with the annual approach can be explained by the specific conditions in the study area. The fertile soils allow high yields from the intensive production of crops with high market prices. Furthermore, in the monthly approach, damage impact factors often reach $100 \%$ for arable land because of the long inundation times that are characteristic for detention areas, whereas in the annual approach a uniform damage impact factor of $50 \%$ is assumed for arable land. Depending on the specific characteristics of flood prone area with respect to the shares of land-use types and the pattern of flooding probability both approaches may result in different risk assessments. The monthly approach is more desirable as it is likely to provide more accurate estimates. Advantages of the annual approach are, however, the low data requirements and a less time-consuming estimation procedure.

If losses for certain flood events in $€$ instead of annual damages in $€$ per year are to be estimated, the monthly 
approach seems even more adequate, since the loss estimates strongly depend on the flood occurrence time. The example of the municipality that was flooded in August 2002 demonstrated the large differences in estimated losses between both approaches.

Estimated losses to the road system also constitute a large proportion of the overall expected losses. Damage potential to the road system in the study area has even increased over the past years. This is because after the extensive inundation of the area during the flood event in summer 2002, several formerly unpaved field lanes were reconstructed with an asphalt cover that bears larger reconstruction costs in case of future inundations.

The sensitivity analysis showed that in flood risk assessments of rural areas with low intensive land use it is more important to evaluate the variation in flooding probability than the variation in land use. It is particularly of importance as large summer floods are becoming more likely to occur. According to Kundzewicz et al. (2005), projected increases in temperature and associated increases in potential water content and intense precipitation are expected to increase summer flooding in most of Central Europe. Not only the flood magnitude, but also the seasonal distribution of flood occurrence is likely to be affected by climate change (Sivapalan et al., 2005). Detention basins and other flood management measures are one option to cope with future changes in flooding probability.

Acknowledgements. The research was jointly funded by the German Ministry of Education and Research (BMBF) within the framework of the project MEDIS - Methods for the Evaluation of Direct and Indirect Flood Losses (No. 0330688), the Germany Research Foundation (Helmholtz Young Scientists Group "Information and modeling systems for large scale flood situations") and the Sixth Framework Program of the European Commission (FLOODsite project, EC Contract number: GOCE-CT-2004-505420). This paper reflects the authors' views and not those of the European Community. Neither the European Community nor any member of the FLOODsite Consortium is liable for any use of the information in this paper.

The authors are grateful to the Landesbetrieb für Hochwasserschutz und Wasserwirtschaft Sachsen-Anhalt and the Wasser- und Schifffahrtsamt Dresden for data provision. S. Itzerott is thanked for her company und support at the field trip.

Edited by: U. Ulbrich

Reviewed by: H. Middelkoop and two other anonymous referees

\section{References}

BfG: Das Augusthochwasser 2002 im Elbegebiet, Bundesamt für Gewässerkunde, http://elise.bafg.de/servlet/is/3967/, 2002.

Citeau, J.-M.: A New Control Concept in the Oise Catchment Area: Definition and Assessment of Flood Compatible Agricultural Activities, FIG working week, Paris, France, 2003.
Consuegra, D., Joerin, F., and Vitalini, F.: Flood Delineation and Impact Assessment in Agricultural Land using GIS Technology, 177-198. In: Geographical Information Systems in Assessing Natural Hazards, edited by: Carrara, A. and Guzzetti, F., Kluwer Academic Publishers, 1995.

Dutta, D., Srikantha, H., Katumi, M.: A mathematical model for flood loss estimation, J. Hydrol., 277, 24-49, 2003.

DVWK: Ökonomische Bewertung von Hochwasserschutzwirkungen, Deutscher Verband für Wasserwirtschaft und Kulturbau, DVWK Mitteilungen 10, 1985.

European Commission (EC): A new EU Floods Directive, http://ec. europa.eu/environment/water/flood_risk/, 2007.

Ellmann, H. and Schulze, B.: Schadenpotentiale in Siedlung/Infrastruktur und Ökologie. In: Möglichkeiten zur Minderung des Hochwasserrisikos durch Nutzung von Flutpoldern an Havel und Oder, edited by: Bronstert, A., Brandenburgische Umweltberichte 15, Universitätsverlag Potsdam. 82-116, http://opus.kobv.de/ubp/volltexte/2005/416/pdf/ Heft_15_Jg_2004.pdf, 2004.

Helms M, Büchele B, Merkel U, and Ihringer J.: Statistical analysis of the flood situation and assessment of the impact of diking measures along the Elbe (Labe) river, J. Hydrol., 267, 94-114, 2002.

Hess, T. and Morris, J.: Estimating the Value of Flood Alleviation on Agricultural Grassland, Agricultural Water Management 15, 141-153, 1988.

Hoes, O. and Schuurmans, W.: Flood Standards or Risk Analyses for Polder Management in the Netherlands, ICID 21st European Regional Conference, Frankfurt (Oder) and Slubice, Germany and Poland, 2005.

Howitt, J., Baldwin, D., Rees, G., and Williams, J.: Modelling blackwater: Predicting water quality during flooding of lowland river forests, Ecological Modelling 203, 229-242, 2007.

Huang, S., Rauberg, J., Apel, H., Disse, M., and Lindenschmidt, K.-E.: The effectiveness of polder systems on peak discharge capping of floods along the middle reaches of the Elbe River in Germany, Hydrol. Earth Syst. Sci., 11, 1391-1401, http://www.hydrol-earth-syst-sci.net/11/1391/2007/ hess-11-1391-2007.pdf, 2007.

International Commission for the Protection of the Elbe River (IKSE): Aktionsplan Hochwasserschutz Elbe, http://elise.bafg. de/servlet/is/5130/, 2003.

Johnson, N. L., Kotz, S., and Balakrishnan, N.: Continuous Univariate Distributions, 2nd ed., Wiley-Interscience, 1994.

Knösche, R.: Fischökologische und fischereiliche Schäden durch Extemhochwasser, Naturschutz und Landschaftspflege in Brandenburg 12, 92-94, 2003.

Kotz, S. and Nadarajah, S.: Extreme value distributions - theory and applications; Imperial College Press, 2000.

Kundzewicz, Z., Ulbrich, U., Brücher, T., et al.: Summer Floods in Central Europe - Climate Change Track?, Natural Hazards, 36, 165-189, 2005.

KTBL: Betriebsplanung Landwirtschaft 2006/07, KTBL Darmstadt, 2006.

KTBL: Standarddeckungsbeiträge, Onlineversion, KTBL Darmstadt, http://www.KTBL.de, 2007.

Lecce, S.: Seasonality of Flooding in North Carolina, Southeastern Geographer 21, 2. 168-175, 2000.

LfL: Veränderte Landnutzungssysteme in hochwassergefährdeten 
Gebieten, Schriftenreihe der Sächsischen Landesanstalt für Landwirtschaft, Heft 12, 2005.

LfUG: Hochwasser in Sachsen - Gefahrenhinweisekarte, Sachsisches Landesamt für Umwelt und Geologie, 2005.

MEDIS: Methods for the evaluation of direct and indirect losses. In: RIMAX-Risk Management of Extreme Flood Events, http://www.rimax-hochwasser.de/fileadmin/RIMAX/download/ Allgemeines/rimax_broschuere_auflage2.pdf, 2007.

Merz, B., Kreibich, H., Thieken, A., and Schmidtke, R.: Estimation uncertainty of direct monetary flood damage to buildings, Nat. Hazards Earth Syst. Sci., 4, 153-163, 2004, http://www.nat-hazards-earth-syst-sci.net/4/153/2004/.

Merz, B. and Thieken, A. H.: Separating natural and epistemic uncertainty in flood frequency analysis, J. Hydrol. 309, 114-132, 2005.

Merz, B., Thieken, A. H., and Gocht, M.: Flood risk mapping at the local scale: concepts and challenges. In: Flood Risk Management in Europe, Advances in Natural and Technological Hazards Research 25, Springer, 231-251, 2007.

Messner, F., Penning-Rowsell, E., Green, C. et al.: Evaluating flood damages: guidance and recommendations on principles and methods, http://www.floodsite.net/html/partner_area/project_ docs/T09_06_01_Flood_damage_guidelines_D9_1_v2_2_p44.pdf, 2007.

Meyer, V. and Messner, F.: National Flood Damage Evaluation Methods, A Review of Applied Methods in England, the Netherlands, the Czech Republic and Germany, UFZ-Discussion Papers $21,2005$.
Neubert, G. and Thiel, R.: Schadenpotentiale in der Landwirtschaft. In: Möglichkeiten zur Minderung des Hochwasserrisikos durch Nutzung von Flutpoldern an Havel und Oder, edited by: Bronstert, A., Universitätsverlag Potsdam, 117-129, http://opus.kobv. de/ubp/volltexte/2005/416/pdf/Heft_15_Jg_2004.pdf, 2004

Penning-Rowsell, E., Johnson, C., Tunstall, S. et al.: The benefits of flood and coastal defence: techniques and data for 2003, Flood Hazard Research Centre, Middlesex University, 2003.

Petrow, T., Merz, B., Lindenschmidt, K.-E., Thieken, A.: Aspects of seasonality and flood generating circulation patterns in a mountainous catchment in south-east Germany, Hydrol. Earth Syst. Sci., 11, 1-14, 2007, http://www.hydrol-earth-syst-sci.net/11/1/2007/.

Pivot, J.-M., Josien, E., Martin, P.: Farm adaptation to changes in flood risk: a management approach, J. Hydrol., 267, 12-25, 2002.

Sivapalan, M., Blöschl, G., Merz, G. and Gutknecht, D.: Linking flood frequency to long-term water balance: incorporating effects of seasonality, Water Resources Research, 41, W06012, doi:10.1029/2004WR003439, 2005.

Todorovic, P. and Woolhiser, D.: On the Time When the Extreme Flood Occurs, Water Resources Research 8, 6, 1433-1438, 1972.

USDA: Economics - Basic Data for Evaluating Floodwater Damages to Crops and Pastures in the Northeast, Technical Note, United States Department of Agriculture, 1978.

YRFCMP: Literature Review for the Development of a SocioEconomic Impacts Assessment Procedure to be applied to the flooding of Qianliang Hu Detention Basin, Hunan Province, China, Yangtze River Flood Control and Management Project, 2003. 